\title{
Manager's Emotional Intelligence, Their Perceived Use of Directive and Supportive Leader Behaviors and Resultant Employee Satisfaction
}

\author{
John Benson \\ Star point Business Solutions \\ PO Box 5010, Hanover, NH 03755 \\ E-mail: johnbenson@starpointbusiness.com \\ Drea Zigarmi \\ University of San Diego and the Ken Blanchard Companies ( \\ 125 State Pl., Escondido, CA 92029, USA \\ Tel: 1-800-728-9730 E-mail: drea.zigarmi@mindspring.com \\ Kim Nimon \\ University of North Texas \\ 4625 Frank Ford Rd., \#407, Dallas, TX 75287 \\ Tel: 1-214-675-4872 E-mail: kim.nimon@gmail.com \\ Accepted: August 23, 2012 \\ Online Published: August 27, 2012 \\ URL: http://dx.doi.org/10.5430/jbar.v $1 n 2$ p30
}

Received: July 24, 2012

doi:10.5430/jbar.v1n2p30

\begin{abstract}
This study examined the possible relationships between a manager's emotional intelligence, direct reports' perceptions of the manager's use of directive and supportive leader behaviors and the direct reports' perceptions of satisfaction with their manager. A total of 109 managers, from a large public utility company located in the northeast, completed the Mayer-Salovey-Caruso Emotional Intelligence Test (MSCEIT), and 525 direct-report employees completed the Leader Action Profile (LAP) assessment. Hierarchical linear modeling analyses of the data revealed positive relationships between emotional intelligence and five specific supportive leadership behaviors, and between emotional intelligence and employee satisfaction with their manager. Suggestions for human resource practitioners, leadership development practitioners, and researchers are made based on the results.
\end{abstract}

Keywords: Emotional intelligence, Directive and Supportive leader behaviors, Transactional leadership, Full-range leadership

\section{Introduction}

In the last three decades, two major areas of investigation have independently been evolving through the efforts of researchers and writers in the fields of psychology, sociology, and industrial and organizational psychology. One area is concerned with the growing interest in affect and emotional experiences at work. There are those who are investigating positive affect within organizations (e.g., Brief \& Weiss, 2002; Diener, 2000; Peterson, 2006; Seligman, 2002; Tsai, Chen, \& Liu, 2007), those who are investigating engagement and its correlates with well-being (e.g., Harter, Schmidt, \& Hayes, 2002; Kahn, 1990, 1992; Macey \& Schneider, 2008; Zigarmi, Nimon, Houson, Witt, \& Diehl, 2009), and those who are investigating emotional intelligence within an organizational setting (e.g., Caruso \& Salovey, 2004; Fineman, 1993; Goleman, 1995; Goleman, Boyatzis, \& McKee, 2002; Weisinger, 1998).

Since the trendsetting book on leadership by James MacGregor Burns (1978) was released, another area of investigation has been evolving around the stimulating transformational/transactional leadership dichotomy which introduces either/or and comparison research for the reader's consideration and choice (e.g., Bass, Avolio, Jung, \& Berson, 2003; Hater \& Bass, 1988; Judge \& Piccolo, 2004; Lowe, Kroeck, \& Sivasubramaniam, 1996; O'Shea, Foti, Hauenstein, \& Bycio, 2009). It is within the context of these two streams of thought; this research study was 
conceived and conducted. Using these two streams of thought as the conceptual starting place, this article seeks to add to the research concerning leadership and emotional intelligence that human resource professionals should consider when recruiting, training, and developing present and future managers and leaders.

\subsection{Purpose}

In order of presentation, the first purpose of this paper is to examine the possible relationships between a manager's emotional intelligence and the use of the leadership behaviors of consideration/support and initiating structure/direction as perceived by their direct reports. A second purpose is to examine the possible relationships between a manager's emotional intelligence and employees' satisfaction with their manager as well as employees' satisfaction with the organization.

The final purpose of this article is to reintroduce and rekindle reader and researcher interest in the "forgotten ones" (Judge, Piccolo, \& Ilies, 2004), namely, consideration/support and initiating structure/direction, which were the backbone for much of the leadership literature of the 1950s, 1960s, and 1970s.

To accomplish these purposes, we have divided the article into: (a) a brief overview of the development of leadership concepts to frame the choice of leadership dimensions assessed in this study; (b) a focused overview of emotional intelligence concepts; (c) an explanation of the hypothesis and research methodology; and (d) a presentation of results, discussion, and implications for human resource professionals and for research.

\section{Overview of Leadership Concepts}

\subsection{Transformational Leadership.}

Since Burns introduced the concept of transformational leadership in 1978, the transformational/transactional leadership dichotomy has become one of the most widely researched leadership questions embraced by researchers, organizational practitioners, and organizational leaders in the last 30 years (Hunt, 1999; Yukl, 1999b). Transformational leaders are defined as those who transform the self-concept of their followers (Bass, 1999; Burns, 1978). Transformational leaders build personal and social identification among followers with the mission and goals of the leader and organization (Bass, Avolio, Jung, \& Berson, 2003; Burns, 1978). Bass and Avolio (1993a) expanded on Burns' concept of a transformational leader by introducing the four "I" behaviors of transformational leadership: idealized influence (charisma), inspirational motivation, intellectual stimulation, and individualized consideration.

Because Burns saw transformational leadership and transactional leadership as ends of a continuum (Bycio, Hackett, \& Allen, 1995), it is possible that Bass decided to define transactional leadership closer to and in keeping with Burns' definition. Bass, however, viewed the transactional and transformational concepts as two separate independent dimensions, each composed of several empirically derived factors (Lowe, Kroeck, \& Sivasubramaniam, 1996; Seltzer \& Bass, 1990). He maintained that the transactional/transformational paradigm is conceptually independent from concepts such as directive versus participative leadership, leader-member exchange theory, and the factor of consideration as measured by the Leader Behavior Description Questionnaire (LBDQ) (Bass, 1999). He maintained that transformational leadership elevates the followers' level of ideals and values to go beyond self-actualization and is concerned with the larger, greater good of groups, organizations, and society (Bass, 1999).

As for transactional leadership, he steadfastly believed that transformational leaders used both transformational and transactional behaviors in their efforts to get things done. He goes on to describe that consideration and initiating structure may be a substitute for transactional leadership as he defines it, but not a substitute for transformational leadership (Bass, 1999; Seltzer \& Bass, 1990). He further explains that transformational leadership is built on and augments transactional leadership (although not vice versa) in contributing to subordinate effort, satisfaction, and effectiveness (Bass, 1999; Seltzer \& Bass, 1990; Waldman, Bass, \& Yammarino, 1990).

After 30 years of research it is now widely held, although sometimes still debated, that the most effective leadership requires a combination of both transformational and transactional leader behaviors (e.g., Bass, 1999; Howell \& Avolio, 1993; Kinicki \& Kreitner, 2006; Kreitner, 2007; Schermerhorn, Hunt, \& Osborn, 2005; O’Shea, Foti, Hausenstein, \& Bycio, 2009). Some of the strongest proponents of transformational leadership have stated that transformational leadership has an augmenting effect on transactional leadership (Bass, 1999; Bass \& Avolio, 1993b; Howell \& Avolio, 1993; Seltzer \& Bass, 1990). The mix ratio of transactional and transformational leader behaviors is dependent on the type of organization, the context, or the situation, and the status or role of the leader (Judge \& Piccolo, 2004; Muczyk \& Adler, 2002; Shivers-Blackwell, 2004). Such a leadership style is often referred to as a full-range leadership (Antonakis, Avolio, \& Sivasubramaniam, 2003; Bass, 1999; Kinicki \& Kreitner, 2006). 
We appreciate and value the contributions that transformational leadership research has made to the larger concepts and questions concerning effective leadership, such as the recognition of the importance of symbolic leader behavior and the role of the leader in making events meaningful for followers. Rather than further discuss the dichotomy, we wish to acknowledge it and briefly focus on the concept of full-range leadership as an extension of the transformational/ transactional paradigm (Antonakis et al., 2003).

\subsection{Full Range Leadership}

Full-range leadership researchers have begun to explore the critical question of the effect of context on the universal applicability of the transformational/transactional leader behaviors (Antonakis et al., 2003). It has been argued that the context in which leader behaviors are used constrains the use of certain behaviors that may be considered effective (Lord, Brown, Harvey, \& Hall, 2001). In other words, situations that are not similar could require different leader behaviors which may limit the universal application of a given model or theory. This is one reason why we believe that both the transactional behaviors and the transformational behaviors listed in the Multilevel Leadership Questionnaire (MLQ) need to be expanded. We advocate a tolerance for the exploration of other impactful leader behaviors. The concept of full-range leadership plus the interest in the augmentation effect of transformational/transactional behaviors would call for the exploration of a comprehensive understanding of a wide variety of possible transformational/transactional leader behaviors and their effects. For example, there is some research to suggest that the items contained in Bass and Avolio's original transactional contingency reward scale actually represent two factors that could be labeled explicit and implicit contracts (Goodwin, Wofford, \& Whittington, 2001).

Transformational leadership research findings have dominated the leadership research literature in the last two decades (Judge \& Piccolo, 2004; Judge, Piccolo, \& Ilies, 2004). Contributing to the attractiveness of transformational leadership was the methodological and conceptual deficiencies of the constructs of consideration and initiating structure, the historically predominant theoretical constructs at that time, which may have caused researchers to look elsewhere for insights into effective leadership (Bass, 2008; Hunt, 1999; Judge \& Piccolo, 2004). A second contributing aspect to the popularity of transformational leadership may have been that the literature on consideration and initiating structure had already been pronounced "dead" before the advent of meta-analysis techniques gained prominence in the leadership literature (Hunt, 1999; Judge, Piccolo, \& Ilies, 2004). It is possible that the quality of the meta-analyses done in the last 15 years (e.g., Judge \& Piccolo, 2004; Judge, Piccolo, \& Ilies, 2004; Lowe, Kroeck, \& Sivasubramaniam, 1996) may have aided in the reexamination and confirmation of the validity of these constructs.

It is possible that the underlying history and meaning of a broader and more comprehensive definition of full-range leadership, lies in a culmination and convergence of many earlier leadership theories, including leadership grid, contingency theory, situational leadership and path-goal theories, which contain a much wider range of specific behaviors than the transactional behaviors of contingency reward and management by exception as defined by Bass and Avolio. The limitations of the definitional constraints inherent in the use of the MLQ may have contributed to a false and needless bifurcation of the full range of behaviors leaders must consider in order to be effective. Judge, Piccolo, and Ilies note:

Since 1980, there have been only a handful of empirical journal articles on Consideration or Initiating Structure, and there have been none done since 1987. These behaviors seem to be in danger of being viewed as historical artifacts in leadership research - important artifacts - but artifacts of little contemporary relevance nonetheless (Judge et al., 2004, p. 43).

By not incorporating some of the work of the previous 30 years of leadership studies in more recent transformational/transactional leadership research, several un-intended outcomes seem to have resulted. First, an appearance of better or best has been attributed to transformational leadership behaviors over transactional leader behaviors. Second, a lack of understanding of augmentation effects that each type of leader behavior has on the other pervades the leadership literature because the lesser of the two dimensions, transactional behaviors, is not fully appreciated through the valid, researched leader behaviors of the past. Finally, historically valid, researched leader behaviors are not fostered or incorporated into a comprehensive "full-range" leadership picture of the influence practices possible for an individual to use when trying to be an effective leader.

We believe that the emphasis on transformational leadership research/transactional leadership research, as defined by the MLQ, has created an imbalance of information and knowledge that relates to understanding the total leadership construct. If full-range leadership is to become prominent and accurate in explaining leadership effectiveness, then: 
(a) researchers must expand their definition of transactional leadership, and (b) the balance between transformational and transactional (expanded) leadership research must be restored and examined.

\subsection{Transactional Leadership}

Bass and Avolio (1993a) defined transactional leadership as an exchange relationship between leader and follower to meet their own self-interests. It means that followers agree with, accept instructions from, or comply with the leader in exchange for praise, rewards, and resources, or the avoidance of disciplinary action (Bass et al., 2003; Burns, 1978). Transactional leadership has come to be defined through contingent reward and management-by-exception behaviors (Bass, 1999). Transactional leaders abide by the organization's cultural rules, procedures, and norms, where transformational leaders set out to understand the culture and then create change to align the organization with a new vision (Bass, 1998; Bass \& Avolio, 1993a; Lowe, Kroeck, \& Sivasubramaniam, 1996).

\subsubsection{The Constructs of Consideration and Initiating Structure}

The definitions of the terms consideration and initiating structure have stayed relatively constant over the years. Consideration is defined as the extent to which a leader engages in two-way communication indicative of friendship, mutual trust, and respect, and demonstrates warmth in the relationship between leader and follower (e.g., Bass, 1985, 2008; Fleishman \& Simmons, 1970; Halpin, 1954; Judge, Piccolo, \& Ilies, 2004). Initiating structure is defined as the extent to which the leader plays a very active role in directing activities through planning, communicating information, scheduling, evaluating, trying out new ideas, and defining his or her role and the roles of their direct reports, which shapes goal attainment (e.g., Bass, 1985, 2008; Fleishman \& Simmons, 1970; Halpin, 1954; Judge, Piccolo, \& Ilies, 2004).

Avolio and Bass saw the value of these two previously credible leadership factors. They stated:

Bass's model cuts across these two dimensions. Initiation can be transactional or transformational. So can consideration. The transformational leader may provide a new strategy or vision to structure the way to tackle a problem. The transactional leader may clarify the "right" way of doing things. Likewise, consideration for a subordinate's current needs and self-interest is likely to be transactional; whereas consideration for a subordinate's long-term personal development in alignment with organizational needs is transformational leadership (Avolio \& Bass, 1988, p. 36).

What is important is that these two proven leader behavior categories (consideration and initiating structure) can account for, explain, or produce outcomes such as follower motivation, job satisfaction, employee work motivation, and related desired outcomes. The importance and impact of consideration and initiating structure leadership behaviors is supported by both recent research (e.g., Judge \& Piccolo, 2004; Judge, Piccolo, \& Ilies, 2004; Yukl, Gordon, \& Taber, 2002) and past research (e.g., Fleishman, 1998; Fleishman \& Harris, 1962; Fleishman \& Peters, 1962; Fleishman \& Simmons, 1970; Halpin, 1954, 1957). These and other studies indicated moderately strong relationships exist between consideration and initiating structure and leadership outcomes, such as follower motivation, job satisfaction, job performance, satisfaction with leader, and leader effectiveness (Judge et al., 2004).

The Judge, Piccolo, and Ilies (2004) meta-analysis indicated that the leadership behaviors of consideration and initiating structure were strongly correlated to effectiveness measures such as leader job performance $(\dot{p}=.25$ for consideration, $\dot{p}=.24$ for structure), follower satisfaction with leader $(\dot{\mathrm{p}}=.78$ for consideration, $\dot{\mathrm{p}}=.33$ for structure), follower job satisfaction ( $\dot{\mathrm{p}}=.46$ for consideration, $\dot{\mathrm{p}}=.22$ for structure), follower motivation ( $\dot{\mathrm{p}}=.50$ for consideration, $\dot{\mathrm{p}}=.40$ for structure), and leader effectiveness $(\dot{\mathrm{p}}=.52$ for consideration, $\dot{\mathrm{p}}=.39$ for structure).

In addition, Judge and Piccolo (2004) conducted a second meta-analytic study to determine the validity of full-range leadership, which is comprised of transformational, transactional, and laissez-faire leadership styles. They concluded that transactional leadership behaviors (contingent reward and management by exception) were nearly as valid as transformational leadership in predicting influence outcomes. This could imply that augmentation possibilities might be even greater if the concept of the transformational/transactional leader or the "full range" of leader behaviors incorporated more diverse micro-dimensions such as consideration and initiating structure. These findings would imply that when taking an in-depth approach to the definition of the "full range" of leadership behaviors, researchers should consider the inclusion of early leadership behaviors such as consideration and initiating structure.

\subsubsection{Directive (Initiating Structure) and Supportive (Consideration) Behaviors}

One of the traditional quadrant models built from the dimensions of initiating structure and consideration that has been used over the last 40 years is the Situational Leadership ${ }^{\circledR}$ Model developed by Hersey and Blanchard. Hersey 
and Blanchard have gone their separate ways conceptually, and Blanchard and his colleagues developed the Situational Leadership ${ }^{\circledR}$ II Model (Blanchard, Zigarmi, \& Zigarmi, 1985). The conceptual foundation of the SLII ${ }^{\circledR}$ Model has its roots in the early Ohio State and Michigan State studies which advocated the fundamental concepts of initiating structure/task and consideration/relationship behaviors (Blanchard, Zigarmi, \& Nelson, 1993).

Blanchard and his coauthors defined initiating structure behavior, which they labeled "directive behavior," as the extent to which a leader engages in one-way communication; spells out the employee's role and tells the employee what to do, when to do it, and how to do it; and then closely supervises performance (Blanchard, 1991; Blanchard, Zigarmi, \& Zigarmi, 1985; Zigarmi, Blanchard, O'Connor, \& Edeburn, 2005; Zigarmi, Blanchard, \& Zigarmi, 1988). They defined consideration behavior, which they labeled "supportive behavior," as the extent to which a leader engages in two-way communication, listens, provides support and encouragement, facilitates interaction, and involves the employee in decision making (ibid).

Blanchard and his coauthors took a similar approach to that of Yukl et al. (2002) by developing a more specific and detailed list of initiating structure/task and consideration/relationship behaviors based on a consolidation of past research (Blanchard et al., 1985; Zigarmi et al., 1988). Blanchard's specific list of seven Directive Behaviors (initiating structure/task) were goal setting, developing action plans, clarifying roles, showing how, evaluating, establishing timelines, and setting priorities (Zigarmi et al., 1988; Zigarmi, Blanchard, \& Edeburn, 1997; Zigarmi et al., 2005). Blanchard's seven specific Supportive Behaviors (consideration/relationship) were listening, praising, organizational information sharing, individual information sharing, problem-solving, asking for input, and providing rationale (ibid).

The directive and supportive behaviors outlined by Blanchard are the 14 specific leadership behaviors that were analyzed in this present study using the Leader Action Profile (LAP) instrument. This study used a version of the traditional dimensions of initiating structure (direction) and consideration (support) to examine how leader emotional intelligence is related to employee satisfaction with their leaders, something that has not been researched until now.

\section{Overview of Emotional Intelligence Concepts}

For two millennia, emotions were not considered part of the intelligence domain, as evidenced by historical accounts of philosophical debates that occurred among early Roman and Greek philosophers. These philosophers thought emotion was too unpredictable to be part of rational thought (Grewal \& Salovey, 2005). The concept of social intelligence as advanced by Edward Thorndike in 1920 was considered abstract and unproven until 1983, when Harvard psychologist Howard Gardner asserted that there were seven distinct forms of intelligence, one of which Gardner named "intrapersonal intelligence," which has several parallels to theories of emotional intelligence (Grewal \& Salovey, 2005).

Gardner's work was germinal to the prominent emotional intelligence theorists, such as Salovey and Mayer, Bar-On, and Goleman (Dulewicz, Higgs, \& Slaski, 2003). Since the work by the theorists in the 1990s, especially Goleman's widely read book published in 1995, interest in emotional intelligence research and knowledge has grown tremendously in the fields of sociology, psychology, organizational behavior, and leadership (Chrusciel, 2006; Salovey \& Grewel, 2005). Many scholars now believe that personal achievement and interpersonal satisfaction are highly dependent on emotional intelligence competencies (Devrim, Nadi, Mahmut, Mustafa, \& Mustafa Kemal, 2005; Mayer, Salovey, \& Caruso, 2004). Other scholars have yet to accept the validity of emotional intelligence (e.g., Conte, 2005; Landy, 2005; Locke, 2005), creating a divide as to the value and validity of emotional intelligence theory.

Emotional intelligence has become integrated into the organizational context, as it is now studied and practiced worldwide by researchers, consultants, training firms, and leadership coaches (Van Dijk \& Freedman, 2007). Emotional intelligence is considered an important element for developing leaders, as research studies have shown a positive correlation with leadership success (e.g. Duckett \& Macfarlane, 2003; Gardner \& Stough, 2002; Vrba, 2007).

Stemming initially from the field of psychology (Emmerling \& Goleman, 2003), the application of emotional intelligence assessment and training has permeated the field of organizational development, especially in efforts to develop exceptional leaders (Kerr, Garvin, Heaton, \& Boyle, 2006). The development of the emotional intelligence construct addressed a gap in psychology: specifically, how individuals differ in emotional abilities (Salovey \& Grewal, 2005). Emotional intelligence is considered complementary to cognitive abilities of technical intelligence (Brown \& Moshavi, 2005; Cherniss, 2000; Devrim et al., 2005; Hoffman \& Frost, 2006). Unlike IQ, which is based on technical knowledge, emotional intelligence uses emotion as a means for processing information and making 
decisions (Ciarrochi \& Mayer, 2007). The definition of emotional intelligence within self and others, is "the ability to perceive emotions, to access and generate emotions so as to assist thought, to understand emotions and emotional meanings, and to reflectively regulate emotions so as to promote both better emotions and thought" (Salovey \& Caruso, 2004).

\subsection{Three Theories of Emotional Intelligence}

Since the early 1980s, emotional intelligence has diverged into three major theoretical models (Emmerling \& Goleman, 2003) which differ in terms of what falls into the emotional intelligence domain (Dulewicz et al., 2003). Bar-On in 1988 and 1997, Salovey and Mayer in 1990, and Goleman in 1995 account for the three major theoretical models. The Mayer and Salovey model is considered an ability model of emotional intelligence, while the Bar-On and Goleman constructs are considered mixed models of emotional intelligence (Mayer, Salovey, \& Caruso, 2000). The mixed models differ from ability-based models by including additional personality characteristics such as empathy, flexibility, and assertiveness that result in various behaviors (Freedman, 2003).

\subsubsection{The Ability Model of Emotional Intelligence}

The ability model of emotional intelligence, presented by Mayer and Salovey, consists of four major branches: perceiving emotions, using emotions to facilitate thought, understanding emotions, and managing emotions (Mayer, Salovey, \& Caruso, 2004). Their theory evolved from a need to measure individual differences with regard to emotion that the initial measures of emotional intelligence from the Bar-On model did not address (Emmerling \& Goleman, 2003). The ability model of emotional intelligence is different from other EI theories because the model is the only one with an associated instrument designed to measure ability (Dulewicz et al., 2003). Each branch has a progression from basic to complex skills that can be measured and identified (Mayer et al., 2004). For these reasons, this model and instrumentation were chosen to be used in the study that follows.

Salovey and Grewal (2005) described the four branches as follows: (a) the Perceiving Emotions branch, which relates to the ability to detect emotions in oneself and in others; (b) the Using Emotions branch, which relates to the ability to use emotions in cognitive activities such as problem solving; (c) the Understanding Emotions branch, which relates to the ability to comprehend the complexity of emotional language and emotional relationships; and (d) the Managing Emotions branch, which relates to the ability to regulate emotions in oneself and in others (Salovey \& Mayer, 1990). The four-branch theory is often used in research studies because of its effectiveness and the validity of the associated measurement instrument (Emmerling \& Goleman, 2003).

\section{Emotional Intelligence and Leadership}

The timing in the evolution of both the transformational/transactional leadership research and emotional intelligence research has resulted in most of the emotional intelligence/leadership research being focused on transformational/ transactional leadership behaviors as defined by the MLQ. Multiple studies have focused on how emotional intelligence is an important attribute for leaders when creating positive work conditions that shape organizational culture and job satisfaction (e.g., Bono, Foldes, Vinson, \& Muros, 2007; Daus \& Ashkanasy, 2005; Palmer, Walls, Burgess, \& Stough, 2001; Podsakoff, MacKenzie, Moorman, \& Fetter, 1990; Sosik \& Megerian, 1999; Stein, Papadogiannis, Yip, \& Sitarenios, 2009; Sy, Tram, \& O'Hara, 2006). Research findings have shown a high correlation between emotional intelligence, transformational leadership behaviors, and leader effectiveness and performance (Bono et al., 2007; Duckett \& Macfarlane, 2003; Gardner \& Stough, 2002; Podsakoff et al., 1990; Sosik \& Megerian, 1999; Vrba, 2007).

\subsection{Emotional Intelligence and Leader Directive and Supportive Behaviors}

Eight research studies were identified that involved an analysis of the relationship between elements of emotional intelligence and elements of transformational/transactional leadership (Barling, Slater, \& Kelloway, 2000; Duckett \& Macfarlane, 2003; Gardner \& Stough, 2002; Kellet, Humphrey, \& Sleeth, 2006; Leban \& Zulauf, 2004; Palmer et al., 2001; Sosik \& Mergerian, 1999; Vrba, 2007). Five studies used Bass and Avolio's (1995) MLQ leadership questionnaire (Barling et al., 2000; Gardner \& Stough, 2002; Leban \& Zulauf, 2004; Palmer et al., 2001; and Sosik $\&$ Mergerian, 1999). Of the five studies which used the MLQ, only two studies show any correlation between leader emotional intelligence scores and the transactional leadership score of contingency reward (Gardner \& Stough, 2002; Palmer et al., 2001).

A search of the literature revealed a lack of research data that addressed how emotional intelligence relates to the leadership behaviors of direction (initiating structure) and support (consideration), the focus of this study. One study was found that examined the behavior of empathy and the emergence of task and relations leaders (Kellet, Humphrey, \& Sleeth, 2006). The combination of the limitations of MLQ instrument examination and the lack of other specific 
leader behaviors in the transformational/transactional paradigm or full-range leadership research has led to a gap in research which this study helps to close.

\section{Method}

\subsection{Design and Hypotheses}

This study has four fundamental hypotheses concerning the relationship between the perceived leadership behaviors of direction (initiating structure) and support (consideration) and the emotional intelligence of the leader. Followers were asked to describe the leadership behaviors of direction and support used by the leader as well as their satisfaction with the leader and the organization, and leaders were asked to describe their emotional awareness. It is hypothesized that:

1) Leader emotional intelligence positively relates to others' report of the use of directive (initiating structure) leadership behaviors.

2) Leader emotional intelligence positively relates to others' report of the use of supportive (consideration) leadership behaviors.

3) Leader emotional intelligence positively relates to others' report of satisfaction with leader.

4) Leader emotional intelligence positively relates to others' report of satisfaction with the organization.

Given the recent lack of research on the leader behaviors of direction and support, the hypotheses listed above, the importance of leader emotional intelligence stressed in literature, and the call for a multisource rating studies to establish an accurate picture of the relationship between emotional intelligence and leader behaviors (Harms \& Crede, 2010), the following methodology is explained in order to set the stage for the findings that follow.

It should be noted that there are two different data sources, the managers themselves and the managers direct reports in which managers rated their emotional intelligence through the MSCEIT and the direct reports rated the use of directive and supportive behaviors through the LAP. The data was obtained from different sources therefore avoiding common method bias.

\subsection{Sample and Procedures}

The population for this study was organizational managers who were employed at a large U.S. public utility company located in the northeast. All the managers in the company (150 managers) were invited to participate in the study. Participants in the study had to be organizational managers who had three or more direct- reports. The manager and the manager's direct-reports had to have access to the Internet in order to access the data collection surveys. The managers were asked to fill out an abilities-based assessment for emotional intelligence and were asked to request that their direct reports complete a multirater assessment for leadership behavior. The managers' and employees' participation was voluntary. The managers gave informed consent before participating in the study. The final sample size was 109 managers and 525 direct reports.

The manager sample was analyzed for gender (males $=89$, females $=20)$, age $(20-29=2,30-39=4,40-49=41$, $50-59=51$ and 60-69=7), ethnicity (Caucasian $=106$, Black=1, not reported=2), and management level (director $=10$, manager $=32$, and supervisors $=67$ ). The data from each survey required formatting and treatment in order to conduct the analysis. Consideration of the treatment concerned missing data, survey question, and Likert-type scale logic. The results for all assessments were sent to the researchers by the survey host company in Excel format.

\subsection{Measures}

\subsubsection{Emotional Intelligence}

The Mayer-Salovey-Caruso Emotional Intelligence Test (MSCEIT) was used to measure the participating managers' emotional intelligence (MHS Inc., 2002). The MSCEIT assessment is a self-test that measures emotional intelligence abilities. The assessment contains 141 items and takes 30 to 45 minutes to complete. The raw data report provided quantitative numerical scores in each of the four branches of emotional intelligence: perceiving emotion, facilitating thought, understanding emotion, and managing emotion. In addition, the report gave a total numerical score for overall emotional intelligence. Reported alpha coefficients for the four subscales were: Perceiving Emotions, .91; Facilitating Thought, .79; Understanding Emotion, .80; and Managing Emotion, .83 (Mayer, Salovey, Caruso, \& Sitarenios, 2003).

An ability-based model was used in this study for two reasons. First, there has been some preliminary evidence to suggest that trait-based instruments are more susceptible to faking than ability-based instruments (Day \& Carroll, 2008). One well-known EI instrument even includes a scale to assess dishonest responding (Bar-On, 1997). A variety 
of definitions for emotional intelligence has given rise to a variety of assessment devices (Harms \& Crede, 2010). These different devices have shown greater or lesser strength correlations, with trait-based instrumentation showing stronger correlations with leadership instruments than ability-based instruments (Harms \& Crede, 2010).

The second reason for the choice of an ability-based model is that trait-based measures often included a wide array of trait capabilities and personal characteristics such as conscientiousness, self-confidence, and resilience which seemed outside the scope of the definition given on previous pages. It has been found that trait-based instrumentation shows greater correlations with selected leadership criteria (Harms \& Crede, 2010). By using an ability-based model we hoped to reduce the number of extraneous traits contained in a mixed or a trait-based model that might correlate with leadership variables (Day \& Carroll, 2008) and lead to spurious conclusions.

The MSCEIT was chosen for several reasons. First, the assessment is the only one that can be considered a criterion report, measuring ability and performance, which is considered the "gold standard" for psychometric testing (Mayer, 2007). Second, the MSCEIT has little overlap with personality assessments, whereas other emotional intelligence assessments do overlap, especially with the Big 5 personality assessments (Conte, 2005). Third, of all the assessments, the MSCEIT has the most evidence of being a comprehensive and sound psychometric measurement (Daus \& Ashkanasy, 2005; Mayer et al., 2003). Finally, the ability-based theory of emotional intelligence is considered by some as the only valid model of emotional intelligence (Daus \& Ashkanasy, 2005).

The MSCEIT has two available scoring methods: general an expert. The general scoring methods uses the answers from a population of 5000 people that comprise the normative sample to determine correct answers (Mayer, et al., 2002). The experts scoring method uses answers from 21 emotional intelligence experts from International Society for Research in Emotions rather than the normative sample of 5000 to determine the correct answers (Mayer., et al.., 2002). The general scoring method was used for this study because it is the recommended method and because there is a high correlation (.90) between the two scoring methods, resulting in little difference in the data.

\subsubsection{Leadership Behaviors}

The Leader Action Profile (LAP) was used to measure the direct reports' perception of the manager's frequent use of Directive and Supportive Behaviors. The LAP also measures how satisfied the manager's direct reports are with their manager and how satisfied the employees are with their organization. The LAP assessment, based on the Situational Leadership $^{\circledR}$ II Model, has seven directive and seven supportive subscales. Each respondent to the assessment was asked to rate the frequency with which his or her manager uses specific directive and supportive leadership behaviors, as well as how satisfied the employee is with his or her manager and with the organization.

The LAP profile is a 16-subscale, 50-question assessment that uses a 6-point Likert-scale response possibility and is designed to measure the perceived frequency of use of Directive and Supportive Behaviors. The possible answers range from almost never (less than 10\% of the time) to almost always (more than $90 \%$ of the time). Twenty-one of the questions are related to Supportive Behavior, and 21 of the questions are related to Directive Behavior. The remaining eight questions are related to satisfaction with the leader and the organization. Within each of the Direction and Support scales, there are several subscales.

The seven Directive subscales (three items per subscale) in the LAP Other instrument have shown alpha coefficients of; Goal Setting, (i.e. This leader talks with me in great detail about my goals) .76; Action Planning, (i.e. This leader and I discussed the action steps needed to accomplish my work goals) .76; Defining Roles, (i.e. This leader goes into detail when he or she defines my job to me) .61; Showing How, (i.e. This leader shows me how to do the tasks connected with my job) .81; Evaluating, (i.e. This leader compares my work to clear performance standards) .87; Setting Timelines, (i.e. This leader sets clear timelines for me to accomplish my work) .59, Setting Priorities, (i.e. This leader sets priorities for the work I am to accomplish) .62; and Direction, (total score) .72.

The alpha coefficients obtained for the seven Support subscales (three items per subscale) were: Listening, (i.e. This leader makes time to listen to my questions or problems) .86; Praising, (i.e. This leader praises people for good performance) .80; Sharing Information about the Organization, (i.e. This leader keeps me informed about what is happening in the organization) .89; Sharing Information about Self, (i.e. This leader shares information about him or herself) .88; Facilitating Problem Solving, (i.e. This leader helps me explore alternative solutions to work problems) .85; Asking for Input, (i.e. This leader asks me for input on various work issues) .82; Giving Rationale, (i.e. This leader explains to me why he or she has taken various courses of action) .86; and Support (total score), .91, from various organizational samples (Unpublished manuscript from the Ken Blanchard companies, 2010).

The alpha coefficient for the Satisfaction with Leader subscale (i.e. this leader has earned my trust and confidence) was .81 and for the Satisfaction with Organization subscale (i.e. I feel good about the way this company treats its 
employees) was .89. The alpha coefficients found in this study were; Direction .90 , Support .95 , Satisfaction with Leader .90, and Satisfaction with Organization .88 (Benson, 2009).

The LAP has been is a correlated with the Leader Behavior Description Questionnaire (LBDQ-XII ${ }^{\circledR}$ 1962, The Ohio State University, Stogdill, 1963), which measures initiating structure and consideration. The Direction scale on the LAP correlates with the Initiating Structure scale on the LBDQ-XII $(F=.5794, p=.0001, \%$ of variance, 33.22, $\mathrm{N}=101)$. The Support scale on the LAP correlates with the Consideration scale on the LBDQ ( $\mathrm{F}=.7211, \mathrm{p}=.0001, \%$ of variance, 51.98. $\mathrm{N}=101$ ) (Ken Blanchard Companies unpublished study, February, 2010).

The LAP was chosen because the concept of direction and support, while similar to consideration and initiating structure, has items which are only concerned with the direct interaction with employees in a one-to-one context. A close examination of the LBDQ shows items concerned with both the team context and one-to-one context yet is not reported as such. Since the full-range leadership research is sensitive to the limitations of context, and we were correlating to emotional intelligence concepts to employee perceptions we decided not to complicate the possibilities by including employee perceptions that would have to be made in both the team context and one to one context.

\subsection{Analysis}

Hierarchical linear modeling (i.e., multilevel) formed the basis of this study's analyses to account for the lack of independence in our data given that groups of employees were supervised by the same manager. With multilevel techniques, variables are entered into models as either fixed or random effects. For example, nesting employees within managers and defining the manager-level intercept term as a random effect allows variance in manager-level intercepts to be modeled, which in turn estimates the between-manager variance in employee data. Variances for variables that are defined as fixed effects are assumed to be zero.

The relationship between the manager's emotional intelligence and the employees' perceptions of their manager's leadership behaviors was estimated by analyzing two-level hierarchical linear models, where employees were nested within managers. Employee responses to the leadership survey were modeled at Level 1, and manager responses to the emotional intelligence survey were modeled at Level 2. With the exception of the Level 2 intercept, all variables were modeled as fixed effects.

We first analyzed unconditional baseline models where the 16 leadership measures were nested within managers to determine how much variance was due to between-manager differences. Next, we tested 90 conditional models where each of the five emotional intelligence measures was modeled as a Level 2 variable to determine how much of the between-manager variance in each of the 16 leadership measures could be explained by one of the emotional intelligence practices. For each of the conditional models, we compared the resulting Akaike Information Criterion (Akaike, 1987) to the AIC from the associated unconditional model to determine if the $\chi^{2}$ difference between the two models was statistically significantly different than zero. We evaluated practical differences between the two models by using the estimate for the Level 2 variance component obtained from the unconditional model and subtracting the Level 2 variance component from the conditional model to determine the percent reduction in Level 2 error variance of the unconditional model (Kreft \& de Leeuw, 1998). Finally, we examined the statistical significance of the emotional intelligence beta weight in the conditional models. For leadership variables where multiple emotional intelligence factors were statistically significant, we ran an all possible subsets regression using software adapted from Nimon, Lewis, Kanes, and Haynes (2008) to define the most parsimonious solution. Emotional intelligence practice scores were grand-mean centered to provide meaningful intercepts.

\section{Results}

Tables 1, 2, and contain the means and variance estimates resulting from the unconditional models. Across all measures, managers accounted for more than $10 \%$ of the variance in employee response to the leadership survey. Tables 4, 5, and 6 present the percent reduction in Level 2 variance for each of the leadership surveys by emotional practice. Although none of the five emotional intelligence dimensions was a significant predictor in reducing the between-manager variance for any of the directive leader behaviors, except Clarifying Roles (Table 4), manager emotional intelligence was a significant predictor for four of the seven supportive leader behaviors and for the satisfaction of boss measure (Table 5). Table 7 presents the most reliable and parsimonious models relating manager emotional intelligence to the study's leadership measures.

$$
\text { Insert Tables 1, 2, 3, 4, 5, 6, and } 7 \text { here. }
$$




\section{Discussion}

As stated above, the three reasons for this research article are: (a) ) to examine the possible relationships between a manager's emotional intelligence and the use of directive and supportive leadership behaviors as perceived by his or her direct reports; (b) to examine the possible relationships between a manager's emotional intelligence and employees' satisfaction with that manager, and employees' satisfaction with the organization, and (c) to reintroduce and rekindle reader and research interest in the "forgotten ones" (Judge, Piccolo, \& Ilies, 2004), namely, consideration and initiating structure, which have been the backbone for much of the leadership literature of the 1950s, 1960s, and 1970s.

\subsection{Relationships between EI and directive/supportive leadership behaviors}

For this study, leadership behaviors were broken into two categories: directive and supportive. Directive leadership behaviors were goal setting, action planning, clarifying roles, showing how, evaluating, establishing timelines, and setting priorities. Supportive leadership behaviors were listening, praising, and sharing information about the organization, sharing information about self, facilitating problem solving, asking for input, and providing rationale. The findings of the study support the notion that emotional intelligence is not significantly related to Directive Behaviors but is significantly related to Supportive Behaviors.

Several of the Supportive Behaviors correlated significantly with emotional intelligence measures. Specifically, four Supportive Behaviors (listening, sharing information about the organization, asking for input, and providing rationale) and the total Supportive Behavior scores were found to be significantly related to emotional intelligence measures (Table 5). Only one of the Directive Behaviors (clarifying roles) was found to be significantly related to emotional intelligence (Table 4).

The findings also revealed that not all of the emotional intelligence branches (perceiving, using, understanding, and managing) were significantly related to leadership behaviors. Only two relationships were found with the using and understanding emotions branches, as well as the total emotional intelligence scores (Table 5). The perceiving and managing emotions branches of emotional intelligence were not shown to have any significant relationships with any of the leadership behaviors.

The results of this study imply that managers with higher emotional intelligence are more likely to engage in supportive behaviors than managers with lower emotional intelligence. It has been posited by previous researchers that personality and emphasis on output or social need could "cause" a display of consideration leader behaviors (Judge, Piccolo, \& Ilies, 2004). This research seems to indicate that when examining the question of supportive or consideration leader behaviors, emotional intelligence skills may also have to be examined. Current leadership thought posits that effective leadership includes high levels of coaching and mentoring, delegating and empowering, and less of the traditional "command and control" approach (American Management Association/Human Resources Institute, 2005) and that interpersonal relationship skills are more important than ever before (Bernthal \& Wellins, 2006), which could mean that the demand for supportive leadership behaviors are also on the rise.

Barling et al. (2000) posited that emotional intelligence predisposes an individual to use different leader behaviors. This study presents evidence that emotionally intelligent leaders are predisposed to clarify roles, listen, share information about the organization, ask for input, and provide rationale more frequently than those with lower emotional intelligence scores. The results of this study suggest that developing a leader's emotional intelligence may help satisfy the thirst for such required leadership competencies.

The relationships found in this research, however, should be seen in perspective. While statistically significant relationships were found, the practical significance should probably be considered important but not overly dramatic or paradigm shifting. For example, the variance between managers for information sharing about the organization was $24 \%$. The HLM model showed an approximate $7 \%$ reduction in this variance as explained by emotional intelligence. Other variables, other than emotional intelligence, account for the differences between managers in this category

In a recent meta-analysis, Harms and Crede (2010) established that trait-based EI instrumentation has repeatedly shown greater correlations with selected leadership variables when using same-source raters $(\dot{p}=.66)$ and multisource raters $(\dot{p}=.13)$. In other words, when managers are asked to rate their own emotional intelligence on trait-based instruments and their own leadership style (same-source raters), a high correlation was found between these two variables. When managers were asked to rate their own emotional intelligence on trait-based instruments and their followers (multisource raters) were asked to describe their leadership styles, the correlations between emotional intelligence and leadership behaviors dropped significantly (Harms \& Crede, 2010). 
In the same meta-analysis, Harms and Crede (2010) found that ability-based measures using same-source and multisource raters were a lot lower (same source, $\dot{p}=.24$; multisource raters, $\dot{p}=.05$ ). This study used an ability-based measure and multisource raters to reach conclusions concerning variance and significance. Our study accounted for more variance across all leader behaviors than the norm found in a recent meta-analysis (Harms \& Crede, 2010). While these relationships were small but significant, the effect sizes are comparable to those found between personality traits and transformational leader behaviors (Bono \& Judge, 2004; Harms \& Crede, 2010). It is for these reasons that we believe there is practical significance to these findings.

\subsection{Relationships between manager EI and employee satisfaction}

Our study found a statistically significant relationship between employee satisfaction with leader and manager emotional intelligence. Specifically, the branch of understanding emotion was significantly related to employee satisfaction with leader (Table 6). There were no significant relationships found between employee satisfaction with the organization and manager emotional intelligence. These findings are consistent with other studies which show leader emotional intelligence correlates with employee job satisfaction (Kellett et al., 2006; Sy, Tram, \& O'Hara, 2006; Wong \& Law, 2002), employee performance (Day \& Carroll, 2004; Wong \& Law, 2002), and employee organizational citizenship behavior (Wong \& Law, 2002). Judge, Piccolo \& Illies, (2004) reported correlations between employee satisfaction and the leader behaviors of consideration and initiating structure but not with any forms organizational commitment or satisfaction.

The ability to understand emotion is the foundation of empathy, a key leadership skill (Kellett et al., 2006). It would seem consistent with the idea that empathetic leaders make the people with whom they are communicating feel as if they are understood. The sense of being understood could result in greater employee satisfaction and therefore greater leadership effectiveness. Our findings are in keeping with others (Kellett et al., 2006; Skinner \& Spurgeon, 2005) who found that people rated highly on empathy garnered attributions of leadership from their peers. They found that cognitive abilities and complex task performance earned actors high ratings on task leadership but not on relationships leadership. As shown in this research, supportive behaviors are related to employee satisfaction, while directive behaviors are not (Table 7). In the leader-employee dyad, communication plays a key part of the leadership, and the leader has frequent opportunities to be empathetic to his or her employees' feelings, needs, problems, and issues.

Again, the relationships found in the research should not be overemphasized. While statistically significant relationships were found, the practical significance should probably be considered important, but not revolutionary. For example, the variance between managers for satisfaction with leader was about $30 \%$. The HLM model showed an approximate $7 \%$ reduction in this variance as explained by the understanding emotions dimension of emotional intelligence. Other variables, other than emotional intelligence, account for the differences between managers in this category. That said, the opinion of these authors is that these findings, for the reasons stated above, have practical significance and should be considered important.

\subsection{The Forgotten Ones}

We believe that to ignore other possible credible leader behaviors that might be incorporated into the full leadership paradigm by defining transactional leadership as contingent reward and management by exception has been a mistake, as evidenced by current research findings. Judge, Piccolo, and Ilies (2004) conducted a meta-analysis that indicated moderately strong relationships exist between consideration and initiating structure and leadership outcomes, including follower job satisfaction, job performance, and follower satisfaction with leader. In addition, Judge and Piccolo (2004) conducted a meta-analytic test for determining the validity of full-range leadership, which is comprised of transformational, transactional, and laissez-faire leadership styles; they determined that transactional leadership was nearly as valid as transformational leadership. With so much research devoted to the four scales on the transformational side of the transactional/transformational leadership paradigm, and defining transactional leadership as contingent reward, some momentum has been lost with regard to the transactional side and the concept of full-range leadership.

The findings from this study revealed significant relationships between self-reported leader emotional intelligence and selected traditional supportive leadership behaviors. These statistically significant relationships are important as they confirm the historical relevance and importance of some of the early work on which the field of leadership is built, namely, the importance of consideration or supportive leader behaviors. It secondarily demonstrates that the emotional intelligence branches of using and understanding emotions is also manifested through the use of leader behaviors such as information sharing about the organization, listening, asking for input, and providing rationale. 
Past research shows that, in general, consideration leader behaviors exhibited stronger relationships with various criteria than did initiating structure (Judge, Piccolo, \& Ilies, 2004). The dimension of support/consideration exhibited stronger relationships with follower satisfaction, job satisfaction, and satisfaction with leader (Judge \& Piccolo, 2004; Judge, Piccolo, \& Ilies, 2004). In prior research, initiating structure (directive leader behaviors) showed stronger correlations with group-organizational performance and leader job performance (Judge, Piccolo, \& Ilies, 2004). In keeping with prior research, this study found strong relationships between supportive leader behaviors and leader emotional intelligence, and almost no relationships with direction or initiating structure.

It might be hypothesized for future study that employees prefer considerate leaders but perform more effectively with leaders who use directive behaviors as well. The use of both initiating structure and consideration leader behaviors is linked to employee motivation and leadership effectiveness, with consideration being somewhat more important (Judge et al., 2004).

The findings in this research have implications for the ongoing study of full-range leadership. Much is known about emotional intelligence and transformational leadership, and the intent of this exploratory research is to begin the process of reawakening the "forgotten" aspects of other possible leadership behaviors, such as initiating structure/direction and consideration/support, for inclusion into new research concerning emerging concepts, such as emotional intelligence.

\section{Implications for Human Resource Professionals and for Researchers}

There are two major implications for human resource professionals and one important implication for those doing research on the topic of leadership. The two implications for HR practitioners are: (a) the impact of a leadership development program may be predicated on the participants' disposition to use various prescribed leader behaviors contained in the program, and (b) one of the values of emotional intelligence training lies in creating the managerial disposition to use supportive behaviors.

\subsection{Implications for HR Practitioners}

\subsubsection{Leadership Training Programs}

Leadership development programs are a viable way to increase leader effectiveness in organizations (Arthur, Bennett, Edens, \& Bell, 2003; Collins \& Holton, 2004), but the effectiveness of those programs depends upon appropriate consideration of the personality factors of the participants in conjunction with the managerial behaviors required by the program (Berr, Church, \& Waclawski, 2000; Colquitt, LePine, \& Noe, 2000). The results of this study might help position where emotional intelligence fits when considering personality factors and leadership behaviors found in various leadership training programs. The results might give human resource practitioners a better understanding of how to develop leaders and also how and why to integrate emotional intelligence training into a leadership development process or curriculum.

\subsubsection{Emotional Intelligence Training}

A major goal of the study was to create a deeper understanding of the relationship between emotional intelligence and specific directive and supportive leadership behaviors to create a pathway for more effective leadership development. This research indicates that a leader's emotional intelligence can be considered an antecedent predictor of the use of supportive (consideration) leader behaviors. It would be helpful for HR practitioners to realize that in order to "predispose" potential managers or practicing managers to use various supportive leader behaviors that may be taught in a particular management development program, an emotional intelligence module or program would be a worthwhile training prerequisite experience. We assume that emotional intelligence can be developed (see Dulewicz \& Higgs, 2004) and using an appropriate emotional intelligence skill-based program, the training could help prospective managers realize the value and impact their own emotional skills might have in creating an environment in which others strive to achieve productive outcomes.

The results of the study are especially significant to human resource and leadership development practitioners who use and rely on programs such as Situational Leadership ${ }^{\circledR}$ in their organization. Blanchard's Situational Leadership ${ }^{\circledR}$ II theory defines development level as a combination of employee competence and commitment, and redefined initiating structure and consideration leader behaviors as directive and supportive leader behaviors. These two basic elements combine to describe the four leadership styles of Directing, Coaching, Supporting, and Delegating. In order to be effective using Situational Leadership ${ }^{\circledR}$ II, a manager needs to be able to diagnose the development level of the employee and also be flexible in his or her applied leadership style. If emotional intelligence can be considered a predictor of supportive behaviors, those leaders with high-emotional intelligence will feel more comfortable using a supportive style than those with low-emotional intelligence. In addition, if emotional intelligence is a predictor of 
supportive behaviors, managers with high-emotional intelligence would be more favorably disposed to use the supportive behaviors, and thus have an easier time adapting their leadership style and shifting between directive and supportive behaviors as required by the development level of their employees.

\subsection{Implications for researchers}

\subsubsection{Expansion of Full Range Leadership Behaviors}

There is one prominent implication for future research: if full-range leadership is to be worthy of its name, it must contain a wider variety of possible behaviors contained in the transactional/transformational paradigm by examining leader behaviors from the past which have demonstrated strong correlations with desirable leadership outcomes such as employee satisfaction, motivation, and performance.

We are proposing that future research on "full range" leadership could begin by expanding beyond the limiting use of contingent reward behaviors and management by exceptions (both active and passive) to include some already proven researched leader behaviors, such as consideration/support and initiating structure/direction. Whether these behaviors should be called transactional or transformational should be determined through future research; however, researchers should reconsider some of the past research from which theories of leadership have evolved if we are to be true to a "full-range" concept.

We agree with Yukl (1999b, Yukl et al., 2002) that research using the MLQ incorporates ambiguous constructs, gives insufficient description of explanatory processes, is biased toward heroic and dyadic leadership, and is ambiguous in regard to transactional leader behaviors. The concept of transactional leadership as measured by the MLQ not only is ambiguous but also omits fundamentally important researched leader behaviors (Yukl, 1999a; Yukl, 1999b; Yukl et al., 2002). Regarding the MLQ and the measurement of transactional leadership behaviors, Yukl writes, “... transactional leadership is now characterized by a diverse collection of (mostly ineffective) leader behaviors that lack any clear common denominator" (Yukl, 1999b, p. 289). The inclusion of the two fundamental dimensions of direction and support in future research would allow researchers to use a variety of instruments which were psychometrically valid to measure leadership behaviors that could be defined as transactional or transformational (see Yukl et al., 2002; Judge, Piccolo, \& Ilies, 2004, for examples of various instruments). Using these two dimensions also helps to close the knowledge gap that may exist concerning the term "full-range leadership" (Antonakis et al., 2003; Bass, 1999; Kinicki \& Kreitner, 2006).

The full-range leadership concept requires future investigation (Antonakis et al., 2003). Other leadership dimensions that are not contained in the MLQ also need to be explored further (see Antonakis \& House, 2002; Yukl, 1999a, 1999b). To continue the research of the last 30 years and comprehensively explore the concept of full-range leadership, leader behaviors such as follower work facilitation, strategic leadership, facilitation of change, and the two factors of explicit and implicit contracts (Goodwin et al., 2001) should be considered. In addition to Goodwin et al's suggestions, we suggest that leader behaviors such as consideration/ support and initiating structure/ direction, be added to the full-range leadership research.

\section{References}

Akaike, H. (1987). Factor analysis and AIC. Psychometrika, 52, 317-332. http://dx.doi.org/10.1007/BF02294359

American Management Association/Human Resources Institute. (2005). Leading into the future: A global study of leadership:2005-2015[Electronic Version]. Retrieved October 15, 2007, from http://www.amanet.org/research/pdfs/HRILeadershipSurv05.pdf

Antonakis, J., Avolio, B. J., \& Sivasubramaniam, N. (2003). Context and leadership: An examination of the nine-factor full-range leadership theory using the multifactor leadership questionnaire. The Leadership Quarterly, 14, 261-295. http://dx.doi.org/10.1016/S1048-9843(03)00030-4

Antonakis, J., \& House, R. J. (2002). An analysis of the full-range of leadership theory: The way forward. In B. J. Avolio \& F. J. Yammarino (Eds.).Transformational and charismatic leadership: The road ahead. (pp. 3-34). Amsterdam, The Netherlands: JAI Press.

Arthur, W., Bennett, W., Edens, P. S., \& Bell, S. T. (2003). Effectiveness of training in organizations: A meta-analysis of design and evaluation features. Journal of Applied Psychology, 88, 234-245. http://dx.doi.org/10.1037/0021-9010.88.2.234

Avolio, B. J., \& Bass, B. M. (1988). Transformational leadership, charisma, and beyond. In J. G. Hunt, B. R. Baglia, H. P. Dachler, \& C. A. Schriescheim (Eds.). Emerging leadership vistas (pp. 29-51). Lexington, MA: Lexington Books. 
Avolio, B. J., Bass, B. M., \& Jung, D. I. (1999). Re-examining the components of transformational and transactional leadership using the multifactor leadership questionnaire. Journal of Occupational and Organizational Psychology, 72, 441-462. http://dx.doi.org/10.1348/096317999166789

Barling, J., Slater, F., \& Kelloway, E. K. (2000). Transformational leadership and emotional intelligence: An exploratory study. Leadership \& Organization Development Journal, 21(3), 157-161. http://dx.doi.org/10.1108/01437730010325040

Bar-On, R. (1997). Emotional quotient inventory: Technical manual. Toronto: Multi-Health Systems.

Bass, B. M. (1985). Leadership and performance beyond expectations. New York: The Free Press.

Bass, B. M. (1998). Transformational leadership: Industry, military, and educational impact. Mahwah, NJ: Erlbaum.

Bass, B. M. (1999). Two decades of research and development in transformational leadership. European Journal of Work \& Organizational Psychology, 8(1), 9-32. http://dx.doi.org/10.1080/135943299398410

Bass, B. M. (2008). The Bass handbook of leadership: Theory, research, and managerial Applications (4th ed.). New York: The Free Press.

Bass, B. M., \& Avolio, B. J. (1993a). Transformational leadership and organizational culture. Public Administration Quarterly, 17(1), 112-121.

Bass, B. M., \& Avolio, B. J. (1993b). Transformational leadership: A response to critiques. In M. M. Chemers \& R. Ayman (Eds.), Leadership theory and research: Perspectives and directions (pp. 49-80). San Diego, CA: Academic Press.

Bass, B. M., \& Avolio, B. J. (1995). Multifactor leadership questionnaire for research. Palo Alto, CA: Mind Garden.

Bass, B. M., Avolio, B. J., Jung, D. I., \& Berson, Y. (2003). Predicting unit performance by assessing transformational and transactional leadership. Journal of Applied Psychology, 88, 207-218. http://dx.doi.org/10.1037/0021-9010.88.2.207

Benson, J. K. (2009). The relationship between emotional intelligence and managers' use of specific directive and supportive behaviors. (doctoral dissertation). Available from ProQuest Dissertations and Theses data base (UMI No. O357437)

Bernthal, P., \& Wellins, R. (2006). Trends in leader development and succession. Human Resource Planning, 29, 31-40.

Berr, S. A., Church, A. H., \& Waclawski, J. (2000). The right relationship is everything: Linking personality preferences to managerial behaviors. Human Resource Development Quarterly, 11, 133-157. http://dx.doi.org/10.1002/1532-1096(200022)11:2<133::AID-HRDQ4>3.0.CO;2-T

Blanchard, K. (1991). Situational view of leadership. Executive Excellence, 8(6), 22-23.

Blanchard, K., Zigarmi, D., \& Nelson, R. B. (1993). Situational leadership ${ }^{\circledR}$ after 25 years: A retrospective. The Journal of Leadership \& Organizational Studies, 1, 21-36. http://dx.doi.org/10.1177/107179199300100104

Blanchard, K., Zigarmi, P., \& Zigarmi, D. (1985). Leadership and the One Minute Manager ${ }^{\circledR}$. New York: William Morrow \& Co., Inc.

Bono, J. E., Foldes, H. J., Vinson, G., \& Muros, J. P. (2007). Workplace emotions: The role of supervision and leadership. Journal of Applied Psychology, 92, 1357-1367. http://dx.doi.org/10.1037/0021-9010.92.5.1357

Bono, J. E., \& Judge, T. A. (2004). Personality and transformational and transactional leadership: A meta-analysis. Journal of Applied Psychology, 89, 901-910. http://dx.doi.org/10.1037/0021-9010.89.5.901

Brief, A. P., \& Weiss, H. M. (2002). Organizational behavior: Affect in the workplace. Annual Review of Psychology, 53, 279-307. http://dx.doi.org/10.1146/annurev.psych.53.100901.135156

Brown, F. W., \& Moshavi, D. (2005). Transformational leadership and emotional intelligence: A potential pathway for increasing understanding of interpersonal influence. Journal of Organizational Behavior, 26, 867-871. http://dx.doi.org/10.1002/job.334

Burns, J. M. (1978). Leadership. New York: Harper \& Row, Publishers.

Bycio, P., Hackett, R. D., \& Allen, J. S. (1995). Further assessments of Bass's (1985) conceptualization of transactional and transformational leadership. Journal of Applied Psychology, 80, 468-478. http://dx.doi.org/10.1037/0021-9010.80.4.468 
Caruso, D. R., \& Salovey, P. (2004). The emotionally intelligent manager: How to develop and use the four key emotional skills of leadership. San Francisco: Jossey-Bass.

Cherniss, C. (2000). Emotional intelligence: What it is and why it matters. Paper presented at the annual meeting of the Society for Industrial and Organizational Psychology. Retrieved December 27, 2006, from http://www.eiconsortium.org/research/what is emotional intelligence.htm

Chrusciel, D. (2006). Considerations of emotional intelligence (EI) in dealing with change decision management. Management Decision, 44, 644-657. http://dx.doi.org/10.1108/00251740610668897

Ciarrochi, J., Forgas, J. P., \& Mayer, J. D. (2001). Emotional intelligence in everyday life: A scientific inquiry. New York: Psychology Press.

Ciarrochi, J., \& Mayer, J. (2007). Applying emotional intelligence: A practitioner's guide (1st ed.). New York: Psychology Press.

Collins, D. B., \& Holton, E. F. (2004). Effectiveness of managerial leadership development programs: A meta-analysis of studies from 1982-2001. Human Resource Development Quarterly, 15, 217-248. http://dx.doi.org/10.1002/hrdq.1099

Colquitt, J. A., LePine, J. A., \& Noe, R. A. (2000). Toward an integrated theory of training motivation: A meta-analytic path analysis of 20 years of research. Journal of Applied Psychology, 85, 678-707. http://dx.doi.org/10.1037/0021-9010.85.5.678

Conte, J. M. (2005). A review and critique of emotional intelligence measures. Journal of Organizational Behavior, 26, 433-440. http://dx.doi.org/10.1002/job.319

Daus, C. S., \& Ashkanasy, N. M. (2005). The case for the ability-based model of emotional intelligence in organizational behavior. Journal of Organizational Behavior, 26, 453-466. http://dx.doi.org/10.1002/job.321

Day, A. L., \& Carroll, S. A. (2004). Using an ability-based measure of emotional intelligence to predict individual performance, group performance, and group citizenship behaviors. Personality and Individual Differences, 36, 1443-1458. http://dx.doi.org/10.1016/S0191-8869(03)00240-X

Day, A. L., \& Carroll, S. A. (2008). Faking emotional intelligence (EI): Comparing response distortion on abilityand trait-based EI measures. Journal of Organizational Behavior, 29, 761-784. http://dx.doi.org/10.1002/job.485

Diener, E. (2000). Subjective well-being: The science of happiness and a proposal for a national index. American Psychologist, 55, 34-43. http://dx.doi.org/10.1037/0003-066X.55.1.34

Devrim, A. M., Nadi, L. D., Mahmut, A., Mustafa, K., \& Mustafa Kemal, O. (2005). The impact of IQ and EQ on pre-eminent achievement in organizations: Implications for the hiring decisions of HRM specialists. The International Journal of Human Resource Management, 16, 701-719. http://dx.doi.org/10.1080/09585190500082998

Duckett, H., \& Macfarlane, E. (2003). Emotional intelligence and transformational leadership in retailing. Leadership \& Organization Development Journal, 24, 309-317. http://dx.doi.org/10.1108/01437730310494284

Dulewicz, V., \& Higgs, M. (2004). Can emotional intelligence be developed? The International Journal of Human Resource Management, 15, 95-111. http://dx.doi.org/10.1080/0958519032000157366

Dulewicz, V., Higgs, M., \& Slaski, M. (2003). Measuring emotional intelligence: Content, construct and

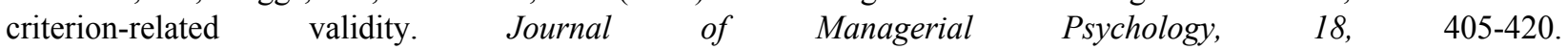
http://dx.doi.org/10.1108/02683940310484017

Emmerling, R., \& Goleman, D. (2003). Emotional intelligence: Issues and common misunderstandings. Issues in Emotional Intelligence. Retrieved August 10, 2007, from http://www.eiconsortium.org/

Fineman, S. (1993). Emotion in organizations. Newberry Park, CA: SAGE Publications Inc.

Fleishman, E. A. (1998). Patterns of leadership behavior related to employee grievances and turnover: Some post hoc reflections. Personnel Psychology, 51, 825-834. http://dx.doi.org/10.1111/j.1744-6570.1998.tb00740.x

Fleishman, E. A., \& Harris, E. F. (1962). Patterns of leadership behavior related to employee grievances and turnover. Personnel Psychology, 15, 43-56. http://dx.doi.org/10.1111/j.1744-6570.1962.tb01845.x

Fleishman, E. A., \& Peters, D. R. (1962). Interpersonal values, leadership attitudes and managerial "success." Personnel Psychology, 15, 127-143. http://dx.doi.org/10.1111/j.1744-6570.1962.tb01855.x 
Fleishman, E. A., \& Simmons, J. (1970). Relationship between leadership patterns and effectiveness ratings among Israeli foremen. Personnel Psychology, 23, 169-172. http://dx.doi.org/10.1111/j.1744-6570.1970.tb01644.x

Freedman, J. (2003). Emotional WHAT? E.Q. Today. Retrieved at www.eqtoday.com/02/emotional.php

Gardner, L., \& Stough, C. (2002). Examining the relationship between leadership and emotional intelligence in senior level managers. Leadership \& Organization Development Journal, 23(2), 68-78. http://dx.doi.org/10.1108/01437730210419198

Goleman, D. (1995). Emotional intelligence. New York: Bantam Books.

Goleman, D., Boyatzis, R., \& McKee, A. (2002). Leadership: Realizing the power of emotional intelligence. Boston: Harvard Business School Press.

Goodwin, V. L., Wofford, J. C., \& Whittington, J. L. (2001). A theoretical and empirical extension to the transformational leadership construct. Journal of Organizational Behavior, 22, 759-774. http://dx.doi.org/10.1002/job.111

Grewal, D., \& Salovey, P. (2005). Feeling smart: The science of emotional intelligence. American Scientist, 93, 330-339.

Halpin, A. W. (1954). The leadership behavior and combat performance of airplane commanders. Journal of Abnormal and Social Psychology, 49, 19-22. http://dx.doi.org/10.1037/h0055910

Halpin, A. W. (1957). The leader behavior and effectiveness of aircraft commanders. In R. M. Stogdill \& A. E. Coons (Eds.). Leader behavior: Its description and measurement, (pp. 52-64). Columbus, OH: Bureau of Business Research.

Harms, P. D., \& Crede, M. (2010). Emotional intelligence and transformational and transactional leadership: A meta-analysis. Journal of Leadership and Organizational Studies, 17, 5-17. http://dx.doi.org/10.1177/1548051809350894

Harter, J. K., Schmidt, F. L., \& Hayes, T. L. (2002). Business-unit-level relationship between employee satisfaction, employee engagement, and business outcomes: A meta-analysis. Journal of Applied Psychology, 87, 268-279. http://dx.doi.org/10.1037/0021-9010.87.2.268

Hater, J. J., \& Bass, B. M. (1988). Supervisors' evaluations and subordinates' perceptions of transformational and transactional leadership. Journal of Applied Psychology, 73, 695-702. http://dx.doi.org/10.1037/0021-9010.73.4.695

Hoffman, J. B., \& Frost, B. C. (2006). Multiple intelligences of transformational leaders: An empirical examination. International Journal of Manpower, 27, 37-47. http://dx.doi.org/10.1108/01437720610652826

Howell, J. M., \& Avolio, B. J. (1993). Transformational leadership, transactional leadership, locus of control, and support for innovation: Key predictors of consolidated business-unit performance. Journal of Applied Psychology, 78, 891-902. http://dx.doi.org/10.1037/0021-9010.78.6.891

Hunt, J. G. (1999). Transformational/charismatic leadership's transformation of the field: An historical essay. Leadership Quarterly, 10, 129-144. http://dx.doi.org/10.1016/S1048-9843(99)00015-6

Judge, T. A., \& Piccolo, R. F. (2004). Transformational and transactional leadership: A meta-analytic test of their relative validity. Journal of Applied Psychology, 89(5), 755-768. http://dx.doi.org/10.1037/0021-9010.89.5.755

Judge, T. A., Piccolo, R. F., \& Ilies, R. (2004). The forgotten ones? The validity of consideration and initiating structure in leadership research. Journal of Applied Psychology, 89(1), 36-51. http://dx.doi.org/10.1037/0021-9010.89.1.36

Kahn, W. A. (1990). Psychological conditions of personal engagement and disengagement network. Academy of Management Journal, 33, 692-724. http://dx.doi.org/10.2307/256287

Kahn, W. A. (1992). To be fully there: Psychological presence at work. Human Relations, 45, 321-349. http://dx.doi.org/10.1177/001872679204500402

Kellet, J. P., Humphrey, R. P., \& Sleeth, R. G. (2006). Empathy and the emergence of task and relations leaders. The Leadership Quarterly, 17, 146-162. http://dx.doi.org/10.1016/j.leaqua.2005.12.003

Kent, T. W. (2005). Leading and managing: It takes two to tango. Management Decision, 43, 1010-1017. http://dx.doi.org/10.1108/00251740510610008 
Kerr, R., Garvin, J., Heaton, N., \& Boyle, E. (2006). Emotional intelligence and leadership effectiveness. Leadership \& Organization Development Journal, 27, 265-279. http://dx.doi.org/10.1108/01437730610666028

Khanin, D. (2007). Contrasting Burns and Bass: Does the transactional-transformational paradigm lives up to Burns' philosophy of transforming leadership? Journal of Leadership Studies, 1(3), 7-25. http://dx.doi.org/10.1002/jls.20022

Kinicki, A., \& Kreitner, R. (2006). Organizational behavior: Key concepts, skills, and best practices (2nd ed.) New York: McGraw Hill.

Kreft, I., \& de Leeuw, J. (1998). Introducing multilevel modeling. Thousand Oaks, CA: SAGE Publications, Inc.

Kreitner, R. (2007). Management (10th ed.). New York: Houghton Mifflin.

Landy, F. J. (2005). Some historical and scientific issues related to research on emotional intelligence. Journal of Organizational Behavior, 26, 411-424. http://dx.doi.org/10.1002/job.317

Leban, W., \& Zulauf, C. (2004). Linking emotional intelligence abilities and transformational leadership styles. Leadership and Organizational Development Journal, 25, 554-564. http://dx.doi.org/10.1108/01437730410561440

Locke, E. A. (2005). Why emotional intelligence is an invalid concept. Journal of Organizational Behavior, 26, 425-432. http://dx.doi.org/10.1002/job.318

Lord, R. G., Brown, D. J., Harvey, J. L., \& Hall, R. J. (2001). Contextual constraints on prototype generation and their multilevel consequences for leadership perceptions. Leadership Quarterly, 12, 311-338. http://dx.doi.org/10.1016/S1048-9843(01)00081-9

Lowe, K. B., Kroeck, K. G., \& Sivasubramaniam, N. (1996). Effectiveness correlates of transformational and transactional leadership: A meta-analytic review of the MLQ literature. Leadership Quarterly, 7, 385-425. http://dx.doi.org/10.1016/S1048-9843(96)90027-2

Macey, W. H., \& Schneider, B. (2008). The meaning of employee engagement. Industrial and Organizational Psychology, 1, 3-30. http://dx.doi.org/10.1111/j.1754-9434.2007.0002.x

Mayer, J. (2007). A new field guide to emotional intelligence. In J. Ciarrochi, J. Forgas, \& J. Mayer (Eds.), Emotional intelligence in everyday life (1st ed.). New York: Psychology Press.

Mayer, J. D., Salovey, P., \& Caruso, D. R. (2004). Emotional intelligence: Theory, findings, and implications. Psychological Inquiry, 15(3), 197-215. http://dx.doi.org/10.1207/s15327965pli1503_02

Mayer, J., Salovey, P., \& Caruso, D. (2000). Models of emotional intelligence. In R. Sternberg (Ed.), Handbook of intelligence. Cambridge, UK: Cambridge University Press. http://dx.doi.org/10.1017/CBO9780511807947.019

Mayer, J. D., Salovey, P., Caruso, D. R., \& Sitarenios, G. (2003). Measuring emotional intelligence with the MSCEIT v2.0, Emotion, 3, 97-109. http://dx.doi.org/10.1037/1528-3542.3.1.97

MHS Inc. (2002). MCSEIT: Mayer-Salovey-Caruso Emotional Intelligence Test. Retrieved February 8, 2008, from https://www.mhs.com/ecom/(iimefljexoh0lx55jxqp4t45)/TechBrochures/MSCEIT.pdf

Mayer, J., Salovey, P., \& Caruso, D. (2002). Mayer-Salovey-Caruso Emotional Intelligence Test, MSCEIT User's Manual. New York: Multi-Health Systems.

Muczyk, J. P., \& Adler, T. (2002). An attempt at a consentience regarding formal leadership. Journal of Leadership \& Organizational Studies, 9(2), 2-17. http://dx.doi.org/10.1177/107179190200900201

Nimon, K., Lewis, M., Kane, R., \& Haynes, R. M. (2008). An R package to compute commonality coefficients in the multiple regression case: An introduction to the package and a practical example. Behavior Research Methods, 40, 457-466. http://dx.doi.org/10.3758/BRM.40.2.457

O'Shea, P. G., Foti, R. J., Hauenstein, N. M. A., \& Bycio, P. (2009). Are the best leaders both transformational and transactional? A pattern-oriented analysis. Leadership, 5, 237-259. http://dx.doi.org/10.1177/1742715009102937

Palmer, B., Walls, M., Burgess, Z., \& Stough, C. (2001). Emotional intelligence and effective leadership [Electronic Version]. Leadership \& Organizational Development Journal 1, 22, 5-8. Retrieved August 22, 2007, from http://proquest.umi.com/pqdweb?did=115922376\&Fmt=7\&clientID=13118\&RQT=309 \&VName=PQD

Peterson, C. (2006). A Primer in Positive Psychology. New York: Oxford University Press.

Podsakoff, P. M., MacKenzie, S. B., Moorman, R. H., \& Fetter, R. (1990). Transformational leader behaviors and their effects on followers' trust in leader, satisfaction, and organizational citizenship behaviors. Leadership Quarterly, 1, 107-142. http://dx.doi.org/10.1016/1048-9843(90)90009-7 
Salovey, P., \& Grewal, D. (2005). The science of emotional intelligence. Current Directions in Psychological Science, 14, 281-285. http://dx.doi.org/10.1111/j.0963-7214.2005.00381.x

Salovey, P., \& Mayer, J. (1990). Emotional intelligence. Imagination, Cognition, and Personality, 9(3), 185-211.

Schermerhorn, J., Hunt, J., \& Osborn, R. (2005). Organizational behavior (9th ed.). Hoboken, NJ: John Wiley.

Seligman, M. (2002). Authentic Happiness. New York: Free Press.

Seltzer, J., \& Bass, B. M. (1990). Transformational leadership: Beyond initiation and consideration. Journal of Management, 16, 693-703. http://dx.doi.org/10.1177/014920639001600403

Shivers-Blackwell, S. L. (2004). Using role theory to examine determinants of transformational and transactional leader behavior. Journal of Leadership \& Organizational Studies, 10(3), 41-50. http://dx.doi.org/10.1177/107179190401000304

Skinner, C., \& Spurgeon, P. (2005). Valuing empathy and emotional intelligence in health leadership: A study of empathy, leadership behavior, and outcome effectiveness. Health Services Management Research, 18(1), 1-11. http://dx.doi.org/10.1258/0951484053051924

Sosik, J. J., \& Megerian, L. E. (1999). Understanding leader emotional intelligence and performance: The role of self-other agreement on transformational leadership perceptions. Group and Organization Management, 24, 367-390. http://dx.doi.org/10.1177/1059601199243006

Stein, S. J., Papadogiannis, P., Yip, J. A., \& Sitarenios, G. (2009). Emotional intelligence of leaders: A profile of top executives. Leadership and Organization Development Journal, 30, 87-101. http://dx.doi.org/10.1108/01437730910927115

Stogdill, R. M. (1963). Manual for the leader behavior description questionnaire-form XII: An experimental revision. Columbus, OH: Bureau of Business Research, Ohio State University.

Sy, T., Tram, S., \& O'Hara, L. A. (2006). Relation of employee and manager emotional intelligence to job satisfaction and performance. Journal of Vocational Behavior, 68, 461-473. http://dx.doi.org/10.1016/j.jvb.2005.10.003

Tsai, W., Chen, C., \& Liu, H. (2007). Testable model linking employee positive moods and task performance. Journal of Applied Psychology, 92, 1570-1583. http://dx.doi.org/10.1037/0021-9010.92.6.1570

Van Dijk, C. F., \& Freedman, J. (2007). Differentiating emotional intelligence in leadership. Journal of Leadership Studies, 1(2), 8-20. http://dx.doi.org/10.1002/jls.20012

Vrba, M. (2007). Emotional intelligence skills and leadership behavior in a sample of South African first-line managers. Management Dynamics, 16(2), 25-35.

Waldman, D. A., Bass, B. M., \& Yammarino, F. J. (1990). Adding to contingent reward behavior: The augmenting effect of charismatic leadership. Group and Organization Management, 15, 381-394. http://dx.doi.org/10.1177/105960119001500404

Weisinger, H. (1998). Emotional intelligence at work: The untapped edge for success. San Francisco: Jossey-Bass Inc.

Wong, C., \& Law, K. S. (2002). The effects of leader and follower emotional intelligence on performance and attitude: An exploratory study. The Leadership Quarterly, 13, 243-274. http://dx.doi.org/10.1016/S1048-9843(02)00099-1

Yukl, G. (1999a). An evaluative essay on current conceptions of effective leadership. European Journal of Work and Organizational Psychology, 8, 33-48. http://dx.doi.org/10.1080/135943299398429

Yukl, G. (1999b). An evaluation of conceptual weaknesses in transformational and charismatic leadership theories. Leadership Quarterly, 10, 285-305. http://dx.doi.org/10.1016/S1048-9843(99)00013-2

Yukl, G., Gordon, A., \& Taber, T. (2002). A hierarchical taxonomy of leadership behavior: Integrating a half century of behavior research. Journal of Leadership \& Organizational Studies, 9(1), 15-33. http://dx.doi.org/10.1177/107179190200900102

Zigarmi, D., Blanchard, K., O’Connor, M., \& Edeburn, C. (2005). The Leader Within. Upper Saddle River, NJ: Pearson Education. 
Zigarmi, D., Edeburn, C., \& Blanchard, K. (1997). Getting to know the LBAII ${ }^{\mathbb{R}}:$ Research, validity, and reliability of the self and other forms (4th ed.). Escondido, CA: The Ken Blanchard Companies.

Zigarmi, D., Nimon, K., Houson, D., Witt, R., \& Diehl, J. (2009). Beyond engagement: Toward a framework and operational definition for employee work passion. Human Resource Development Review, 8, 300-316. http://dx.doi.org/10.1177/1534484309338171

Zigarmi, P., Blanchard, K., \& Zigarmi, D. (1988). SLII ${ }^{\circledR}$ facilitator's guide and appendices. Escondido, CA: Blanchard Training and Development, Inc.

Table 1. Directive Leadership Behaviors Baseline Model Estimates

\begin{tabular}{lrrrc}
\hline Variable & $\begin{array}{c}\text { Estimated } \\
\text { Mean }\end{array}$ & $\begin{array}{c}\text { Within Manager } \\
\text { Variance }\end{array}$ & $\begin{array}{c}\text { Between Manager } \\
\text { Variance }\end{array}$ & $\begin{array}{c}\text { \% of Variance due to } \\
\text { Manager Differences }\end{array}$ \\
\hline Goal setting & 10.56 & 7.61 & 1.58 & $17.50 \%$ \\
Action planning & 10.51 & 13.95 & 2.14 & $13.30 \%$ \\
Clarifying roles & 12.59 & 9.90 & 1.74 & $15.30 \%$ \\
Showing how & 8.79 & 8.52 & 1.57 & $15.50 \%$ \\
Evaluating & 12.62 & 13.07 & 1.91 & $12.80 \%$ \\
Establish timelines & 9.64 & 8.47 & 1.25 & $13.00 \%$ \\
Setting priorities & 9.71 & 7.11 & 1.68 & $19.20 \%$ \\
Directive total & 74.67 & 272.36 & 58.95 & $17.80 \%$ \\
\hline
\end{tabular}

Table 2. Supportive Leadership Behaviors Baseline Model Estimates

\begin{tabular}{lcccc}
\hline Variable & $\begin{array}{c}\text { Estimated } \\
\text { Mean }\end{array}$ & $\begin{array}{c}\text { Within } \\
\text { Manager } \\
\text { Variance }\end{array}$ & $\begin{array}{c}\text { Between Manager } \\
\text { Variance }\end{array}$ & $\begin{array}{c}\text { \% of Variance due to } \\
\text { Manager Differences }\end{array}$ \\
\hline Listening & 14.65 & 8.10 & 2.27 & $22.50 \%$ \\
Praising & 14.29 & 8.24 & 3.30 & $28.80 \%$ \\
Information sharing-org. & 14.25 & 9.25 & 2.80 & $23.90 \%$ \\
Information sharing-self & 12.38 & 11.43 & 1.85 & $14.30 \%$ \\
Facilitating problem solving & 11.51 & 9.49 & 1.26 & $11.70 \%$ \\
Asking for input & 13.80 & 11.96 & 1.89 & $13.80 \%$ \\
Providing rationale & 13.46 & 10.74 & 1.29 & $10.90 \%$ \\
Supportive total & 94.49 & 322.88 & 94.45 & $23.00 \%$ \\
\hline
\end{tabular}

Table 3. Satisfaction Measures Baseline Model Estimates

\begin{tabular}{lcccc}
\hline Variable & $\begin{array}{c}\text { Estimated } \\
\text { Mean }\end{array}$ & $\begin{array}{c}\text { Within } \\
\text { Manager } \\
\text { Variance }\end{array}$ & $\begin{array}{c}\text { Between } \\
\text { Manager } \\
\text { Variance }\end{array}$ & $\begin{array}{c}\text { \% of Variance due to } \\
\text { Manager Differences }\end{array}$ \\
\hline Satisfaction with leader & 19.67 & 14.81 & 6.21 & $29.90 \%$ \\
Satisfaction with org & 20.33 & 13.50 & 1.74 & $11.30 \%$ \\
\hline
\end{tabular}


Table 4. Directive Leadership Behaviors

\begin{tabular}{lccccc}
\hline Variable & Perceiving & Using & Understanding & Managing & Total EI \\
\hline Goal setting & $1.90 \%$ & $3.40 \%$ & $0.20 \%$ & $1.30 \%$ & $1.90 \%$ \\
Action planning & $0.00 \%$ & $0.10 \%$ & $0.00 \%$ & $0.40 \%$ & $0.00 \%$ \\
Clarifying roles & $2.90 \%+$ & $5.20 \%+$ & $8.80 \%+$ & $1.30 \%$ & $7.40 \%{ }^{+}+$ \\
Showing how & $0.10 \%$ & $1.40 \%$ & $2.30 \%$ & $1.40 \%$ & $1.00 \%$ \\
Evaluating & $0.40 \%$ & $5.80 \%$ & $1.40 \%$ & $1.60 \%$ & $2.40 \%$ \\
Establish timelines & $0.70 \%$ & $0.70 \%$ & $2.50 \%$ & $1.30 \%$ & $2.50 \%$ \\
Setting priorities & $0.30 \%$ & $1.10 \%$ & $0.90 \%$ & $0.10 \%$ & $1.00 \%$ \\
Directive total & $0.10 \%$ & $1.20 \%$ & $-0.10 \%$ & $0.10 \%$ & $0.30 \%$ \\
\hline
\end{tabular}

Note. *EI predictor significant at .05 alpha level. +Significant chi-square difference as compared to baseline model.

Table 5. Correlation Coefficients for EI and Supportive Behaviors

\section{Supportive Leadership Behaviors}

\begin{tabular}{lrlcrc}
\hline Variable & Perceiving & Using & Understanding & Managing & Total EI \\
\hline Listening & $3.80 \%^{+}$ & $7.70 \%^{*+}$ & $9.90 \%^{*+}$ & $1.30 \%$ & $9.30 \%^{*+}$ \\
Praising & $0.80 \%$ & $2.00 \%$ & $4.60 \%$ & $0.10 \%$ & $1.50 \%$ \\
Information sharing-org. & $3.40 \%^{+}$ & $5.60 \%^{+}$ & $6.90 \%^{+}$ & $1.10 \%$ & $6.40 \%^{*+}$ \\
Information sharing-self & $3.00 \%$ & $8.80 \%^{+}$ & $1.70 \%$ & $3.80 \%$ & $8.50 \%^{+}$ \\
Facilitating problem solving & $-0.40 \%$ & $5.90 \%^{+}$ & $5.30 \%$ & $-0.20 \%$ & $0.90 \%$ \\
Asking for input & $0.80 \%$ & $10.10 \%^{*+}$ & $10.90 \% \%^{*}$ & $2.50 \%$ & $7.20 \%+$ \\
Providing rationale & $2.00 \%$ & $19.30 \%^{*+}$ & $5.40 \%$ & $-0.50 \%$ & $8.10 \%^{+}$ \\
Supportive total & $2.20 \%$ & $7.10 \%^{*+}$ & $6.10 \%^{+}$ & $0.40 \%$ & $5.90 \%^{+}$ \\
\hline
\end{tabular}

Note. *EI predictor significant at .05 alpha level. +Significant chi-square difference as compared to baseline model.

Table 6. Correlation Coefficients for EI and Supportive Behaviors

\section{Satisfaction Measures}

\begin{tabular}{lccrrr}
\hline Variable & Perceiving & Using & Understanding & Managing & Total EI \\
\hline Satisfaction with leader & $1.60 \%$ & $4.00 \%+$ & $7.00 \%{ }^{*}+$ & $0.80 \%$ & $2.50 \%$ \\
Satisfaction with organization & $-1.00 \%$ & $3.90 \%+$ & $9.00 \%+$ & $2.50 \%$ & $0.20 \%$ \\
\hline
\end{tabular}

Note. $*$ EI predictor significant at .05 alpha level. + Significant chi-square difference as compared to baseline model. 
Table 7. Final Models

\begin{tabular}{|c|c|c|c|c|c|c|c|c|}
\hline & \multirow{2}{*}{\multicolumn{2}{|c|}{ Listening }} & \multirow{2}{*}{\multicolumn{2}{|c|}{$\begin{array}{l}\text { Information } \\
\text { Sharing-Org }\end{array}$}} & \multirow{2}{*}{\multicolumn{2}{|c|}{$\begin{array}{c}\text { Asking } \\
\text { For Input }\end{array}$}} & \multirow{2}{*}{\multicolumn{2}{|c|}{ Providing Rationale }} \\
\hline & & & & & & & & \\
\hline & Est. & SE & Est. & SE & Est. & SE & Est. & SE \\
\hline \multicolumn{9}{|l|}{ Fixed effects: } \\
\hline Intercept & $14.64 * * *$ & .19 & $14.24 * * *$ & .21 & $13.45 * * *$ & .18 & $13.45 * * *$ & .18 \\
\hline Total EI & $.04 *$ & .01 & $.03 *$ & .01 & & & & \\
\hline Using & & & & & $.03 *$ & .01 & $.03 *$ & .01 \\
\hline \multicolumn{9}{|l|}{ Random effects: } \\
\hline Residual $\left(\sigma_{\mathrm{e}}^{2}\right)$ & 8.10 & & 9.25 & & 11.97 & & 10.77 & \\
\hline Intercept $\left(\sigma_{o}^{2}\right)$ & 2.13 & & 2.71 & & 1.71 & & 1.06 & \\
\hline \multicolumn{9}{|l|}{ Fit: } \\
\hline$\chi^{2}$ & -1301.68 & & -1341.18 & & -1386.44 & & -1341.92 & \\
\hline AIC & 2611.37 & & 2690.36 & & 2780.88 & & 2691.85 & \\
\hline
\end{tabular}

\begin{tabular}{|c|c|c|c|c|c|c|}
\hline & \multicolumn{2}{|c|}{$\begin{array}{c}\text { Clarifying } \\
\text { Roles }\end{array}$} & \multicolumn{2}{|c|}{$\begin{array}{c}\text { Supportive } \\
\text { Total }\end{array}$} & \multicolumn{2}{|c|}{$\begin{array}{l}\text { Satisfaction } \\
\text { with Leader }\end{array}$} \\
\hline & Est. & $\mathrm{SE}$ & Est. & $\mathrm{SE}$ & Est. & $\mathrm{SE}$ \\
\hline \multicolumn{7}{|l|}{ Fixed effects: } \\
\hline Intercept & $12.58 * * *$ & .19 & $94.44 * * *$ & .21 & $19.66 * * *$ & .30 \\
\hline Total EI & $.03 *$ & .01 & & & & \\
\hline Using & & & $.17^{*}$ & .01 & & \\
\hline Understanding & & & & & $.07 *$ & .03 \\
\hline \multicolumn{7}{|l|}{ Random effects: } \\
\hline Residual $\left(\sigma_{\mathrm{e}}^{2}\right)$ & 9.90 & & 323.42 & & 14.84 & \\
\hline Intercept $\left(\sigma_{0}^{2}\right)$ & 1.66 & & 89.66 & & 5.86 & \\
\hline \multicolumn{7}{|l|}{ Fit: } \\
\hline$\chi^{2}$ & -1333.53 & & -2205.62 & & -1468.60 & \\
\hline AIC & 2675.07 & & 4419.25 & & 2945.20 & \\
\hline
\end{tabular}

